\title{
Influence of environmental variables on the diatom communities of oligotrophic reservoirs for public water supply (Guarulhos, Southeast Brazil)
}

Influência das variáveis ambientais nas comunidades de diatomáceas de reservatórios oligotróficos para o abastecimento público de água (Guarulhos, Sudeste do Brasil)

\section{Simone Alves de Oliveira ${ }^{1 *}$ and Carlos Eduardo de Mattos Bicudo²}

${ }^{1}$ Núcleo de Pesquisa em Ecologia, Programa de Pós-graduação em Biodiversidade Vegetal e Meio Ambiente, Instituto de Botânica de São Paulo - IBt, Av. Miguel Estéfano, Água Funda, 3687, CEP 04301-902, São Paulo, SP, Brasil

${ }^{2}$ Núcleo de Pesquisa em Ecologia, Instituto de Botânica de São Paulo - IBt, Av. Miguel Estéfano, Água Funda, 3687, CEP 04301-902, São Paulo, SP, Brasil

*e-mail: simonemone123@hotmail.com

Cite as: Oliveira, S.A. and Bicudo, C.E.M. Influence of environmental variables on the diatom communities of oligotrophic reservoirs for public water supply (Guarulhos, Southeast Brazil). Acta Limnologica Brasiliensia, 2018, vol. 30, e211.

Abstract: Aim: Our study aimed at analyzing the diatom community structure of the plankton, periphyton, and surface sediments, and their relationship with the environmental variables of two reservoirs, Tanque Grande and Cabuçu, located in the city of Guarulhos, Metropolitan Region of São Paulo. Methods: Three sampling stations were stablished in each reservoir. Samples of water and periphyton were collected during the dry (August 2013) and the rainy periods (January 2014), while the sediment was sampled only during the dry period. Water abiotic limnological variables were determined and quantitative and qualitative analyses were performed after the oxidation of diatom samples. Results: Both reservoirs presented low values of electrical conductivity, $\mathrm{pH}$ and nutrients. The diatom community was represented by 30 taxa distributed in 20 genera. The diatom diversity was higher in the plankton, with three exclusive species. All taxa collected from the surface sediments also occurred in the plankton. The periphyton was represented by six taxa that were exclusive to this habitat. Conclusion: Our results indicated that the environmental variables were responsible for the limnological changes in the two reservoirs. In the studied reservoirs, the species composition of diatoms differed slightly between the plankton and the surface sediments, while we found a different community in the periphyton, with the presence of exclusive species. The two climatic periods showed differences in the abundance of species, but no considerable differences in the species composition between the two reservoirs were observed.

Keywords: diversity; periphyton; plankton; surface sediments.

Resumo: Objetivo: Nosso estudo teve como objetivo analisar a estrutura da comunidade de diatomáceas do plâncton, do perifíton e de sedimentos superficiais e sua relaçáo com as variáveis ambientais de dois reservatórios, Tanque Grande e Cabuçu, ambos localizados na cidade de Guarulhos, Região Metropolitana de São Paulo. Métodos: Três estaçóes de amostragem foram estabelecidas em cada reservatório. Amostras d'água e perifíton foram amostrados durante os períodos seco (agosto de 2013) e chuvoso (janeiro de 2014), enquanto o sedimento foi amostrado apenas no período seco. Variáveis limnológicas abióticas foram determinadas e análises quantitativas e qualitativas foram 
realizadas após a oxidação das amostras de diatomáceas. Resultados: Os dois reservatórios apresentaram baixa condutividade elétrica, $\mathrm{pH}$ e concentração de nutrientes. A comunidade taxonômica das diatomáceas foi representada por 30 táxons distribuídos em 20 gêneros. A diversidade de diatomáceas foi maior no plâncton, com três espécies exclusivas. Todos os táxons encontrados no sedimento superficial também ocorreram no plâncton. O perifíton apresentou seis táxons exclusivos para esse hábitat. Conclusáo:Nossos resultados indicaram que as variáveis ambientais foram responsáveis pela variação limnológica nos dois reservatórios. Nos reservatórios estudados, a composição de espécies de diatomáceas variou muito pouco entre o plâncton e os sedimentos superficiais, enquanto uma comunidade diferenciada foi encontrada no perifíton, com a presença de espécies exclusivas. Os períodos climáticos mostraram diferenças na abundância das espécies, mas, não foram observadas diferenças consideráveis na composição de espécies entre os reservatórios.

Palavras-chave: diversidade; plâncton; perifíton; sedimentos superficiais.

\section{Introduction}

Ecological modifications in reservoirs might be detected by monitoring the water quality and considering the information accumulated in the sediments either superficial or deposited in layers (Birks \& Birks, 2006). Besides the water and sediment compartments, the periphyton community has an important role in the metabolism of aquatic environments, not only as primary producers but also as regulators of the nutrient fluxes in these ecosystems (Pompêo \& Moschini-Carlos, 2003). The analysis of water physical and chemical characteristics and of the biological features establishes the basis for monitoring the water quality of the reservoir, allowing an integrated evaluation of the instant and extended effects (Lobo et al., 2002).Lacustrine sediments are a valuable source of information of the organisms that are present in the different compartments, and they also constitute a spatial and temporal integrated sample of all the events that occurred during the recent past time (Bennion, 1995; Mozeto, 2004).

In environmental monitoring studies, diatoms are among the main biological indicators, because they quickly respond to the environment changes and are generally abundant in different types of aquatic systems (Dennys, 1991). Furthermore, diatoms have some unique characteristics as for instance ubiquity, specific environmental tolerance spectrum, susceptibility to environmental changes in the short and long term, the presence of a siliceous cell wall that enables the identification when they are deposited in sediments, and high migration rates (Round et al., 1990). Consequently, diatoms have been used for the assessment of processes of eutrophication, acidification, metal contamination, and past climate change (Lobo et al., 2002; Wehr \& Sheath, 2003; Smol, 2008; Smol \& Stoermer, 2010; Bennion et al., 2011).
In view of the increasing degradation of aquatic environments, ecological studies in water bodies that still maintain good water quality conditions are of utmost relevance. In public supply reservoirs, the need for such studies is even more urgent in order to contribute to the maintenance of the ecological quality of these environments.

In Brazil, our knowledge of the diatom diversity in oligotrophic systems still is very scarce (Schneck et al., 2008; Bicudo et al., 2009). Furthermore, most contributions are hitherto restricted to lotic systems of the Southeast and the Southern regions of the country (Salomoni et al., 2006; Bere \& Tundisi, 2010; Moresco et al., 2011). In the state of São Paulo, the study of the diatom composition is a relatively recent subject that have started with Bicudo et al. (1993), who surveyed the phytoplankton community of Rosana hydroelectric power reservoir. A few studies on the taxonomy of periphytic diatoms (e.g. Tremarin et al., 2009, 2010; Faria et al., 2010) and past diatoms (Costa-Böddeker et al., 2012; Fontana et al., 2014) have been carried out and some of them have analyzed ecological aspects of water supply reservoirs (Almeida \& Bicudo, 2014; Zorzal-Almeida et al., 2017; Marquardt et al., 2018). The studies of Wengrat et al. (2015), Marquardt et al. $(2016,2017)$ have described new species of diatoms from oligotrophic systems in the state of São Paulo. The contributions of Fontana \& Bicudo (2009, 2012), Almeida \& Bicudo (2014), Faustino et al. (2016) and more recently of Bartozek et al. (2018) assessed the diatoms from the phytoplankton and surface sediments along a trophic gradient of tropical reservoirs. In the case of the water supply reservoirs of Guarulhos, studies on the diatom community (Moutinho et al., 2007; Barbosa, 2012), and that have assessed the water quality of the reservoirs are scarce (Piasentin et al., 2009; Lacava et al., 2009; Oliveira \& Bicudo, 2017) while no studies have been carried out 
hitherto on the diatoms of the periphyton and surface sediments. Therefore, the present study aimed at characterizing the structure of the diatom community of the plankton, periphyton and surface sediments of two reservoirs of the Guarulhos water supply system and their relationship with the environmental variables, in order to understand the influence of spatial and temporal scales on the diatom distribution and contribute to future studies focused on the understanding of the diatomsenvironment relationships.

\section{Material and Methods}

\subsection{Study area}

The reservoirs Tanque Grande and Cabuçu are located in the city of Guarulhos, São Paulo state, southeast Brazil (2327'49”S, 4632’01”W; Figure 1). Tanque Grande is located in northern

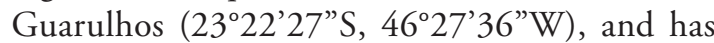
a basin area of $7.75 \mathrm{~km}^{2}$, a storage capacity of $77,401 \mathrm{~m}^{3}$ and a retention time of 7.35 days (Silva et al., 2011; CETESB, 2015). This reservoir

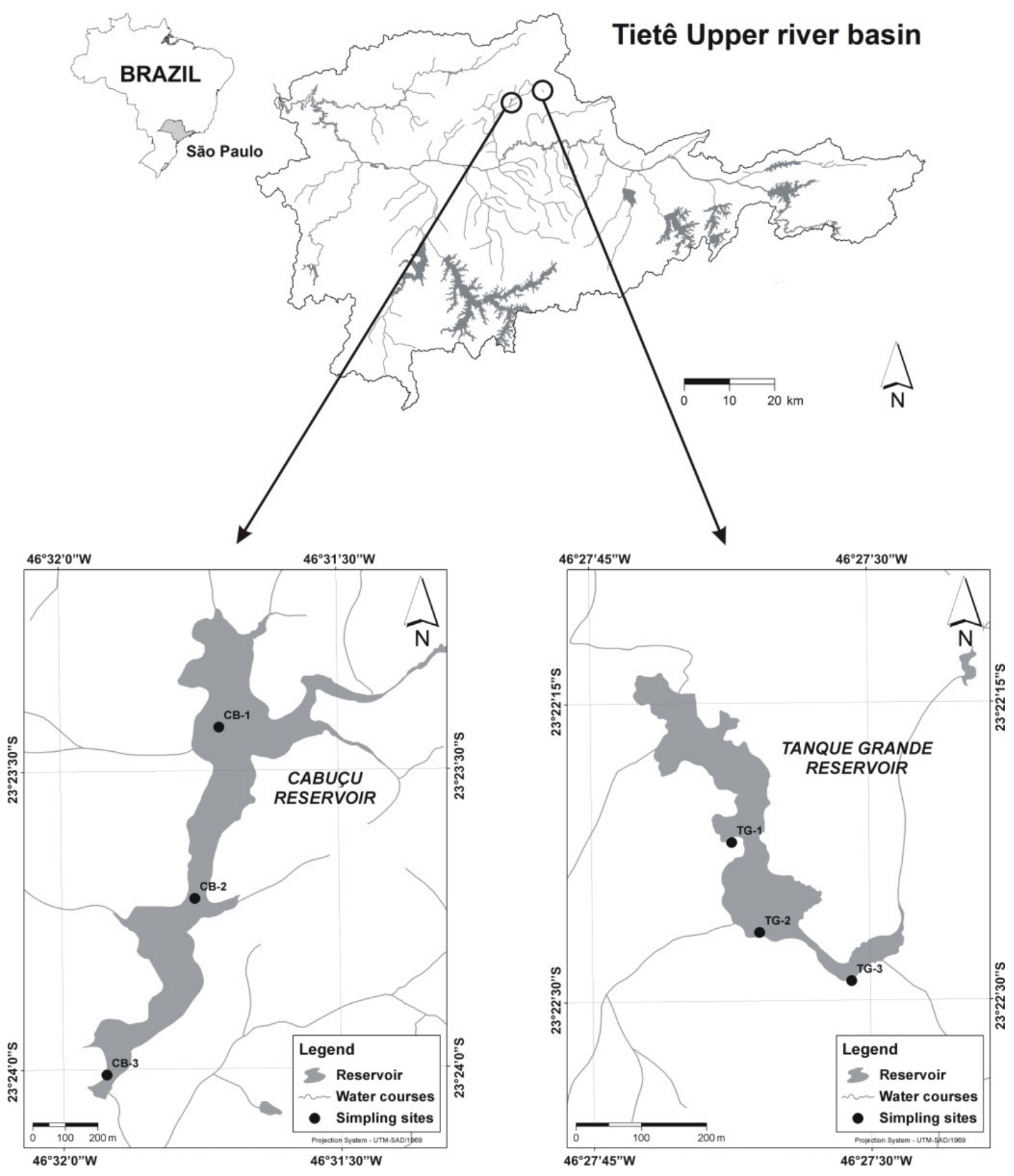

Figure 1. Geographic location of Tietê Upper River Basin and sampling stations in Cabuçu and Tanque Grande reservoirs, São Paulo state, Brazil. 
was built in 1958 and is responsible for $10 \%$ of the water supply in Guarulhos. Cabuçu is located in "Parque Estadual da Cantareira", southern Guarulhos (2224'06”S, 4631'56”W). It has a basin area of $23.8 \mathrm{~km}^{2}$, a storage capacity of $1,767,000 \mathrm{~m}^{3}$ and a retention time of 68.5 days (Barbosa, 2012). The Cabuçu reservoir was built in 1904 and has supplied with water the city São Paulo for more than 60 years when it was deactivated due to the start of operations of the Cantareira system. In 2002, the reservoir was reactivated to contribute to the water supply of Guarulhos (Lacava et al., 2009).

\subsection{Sampling and data analysis}

The selection of sampling stations was based on the size of reservoirs, inflows of tributaries, and the depth of the system. Three stations were established in each of the reservoirs (Figure 1). Samples of water and periphyton were collected during the dry (August 2013) and the rainy periods (January 2014). Because surface sediments constitute a temporal and spatially integrated sample (Smol, 2008), they were collected only during the dry period. For the determination of limnological variables and the analysis of plankton, water samples along a vertical profile (sub-surface, middle and $1 \mathrm{~m}$ above the bottom) were collected using a van Dorn bottle. At both sampling periods, the temperature, $\mathrm{pH}$ and electric conductivity were measured in situ with a Horiba U50 multiparameter portable probe; and samples of water were collected for the analysis of total nitrogen, total phosphorus (Valderrama, 1981) and soluble reactive silicon (Golterman et al., 1978). For the determination of chlorophyll $a$, corrected for phaeophytin, a water sub-sample was filtered through a glass-fiber filter (GF/F Whatman), followed by a $24 \mathrm{~h}$ extraction with $90 \%$ ethanol (Sartory \& Grobbelaar, 1984). Whenever the aquatic macrophyte Eichhornia crassipes (Mart) Solms was present, periphyton samples were obtained by scraping submersed parts of the plant. Plankton and periphyton samples were fixed with an acetic Lugol solution (Bicudo \& Menezes, 2006). Surface sediments were collected with a UWITEC gravity corer, and the top $2 \mathrm{~cm}$ sections of the core were used for analyses.

The trophic State Index (TSI) was calculated according to CETESB (2015) using the data of total phosphorus and chlorophyll $a$.

The oxidation of the diatom organic matter followed the process described in Battarbee (1986). Permanent slides were prepared with Naphrax as mounting medium $(\mathrm{RI}=1.73)$. Diatoms were identified from a population sample using a Zeiss Axioskop 2 plus equipped with phase-contrast and an image capture system, at a magnification of $1000 \times$. Counting was conducted according to Battarbee (1986) and for each sample, the following criteria were considered to establish the quantification limit: the species rarefaction curve, a minimum counting of 400 valves per slide, and a minimum sampling efficiency of 90\% (Pappas \& Stoermer, 1996). These criteria allowed the comparison between communities of different habitats.

All taxa occurring with a relative abundance $\geq 2 \%$ for the plankton and periphyton, and $\geq 1 \%$ for the surface sediments were considered. Species richness was defined as the number of species per sample, and the Simpson's dominance index was calculated using density data. Canonical Correspondence Analysis (CCA) was performed to evaluate the relationship between biological and environmental data matrices, using abiotic data previously transformed by range $\left[\left(x-x_{\text {min }}\right) /\left(x_{\text {max }}-x_{\text {min }}\right)\right]$ and biotic data by log $(\mathrm{x}+1)$. In the CCA, the Monte Carlo permutation procedure (999 permutations) was used to test for significance between species and environmental variables $(p<0.05)$. Analyses were performed in PC-ORD 6.0 (McCune \& Mefford, 2011).

\section{Results}

The sampling periods followed the pattern expected for a tropical region, with mild temperatures during the dry period $\left(18.7^{\circ} \mathrm{C}\right)$ and higher ones during the rainy period $\left(26.8^{\circ} \mathrm{C}\right)$. Water temperature followed the same pattern in both reservoirs, with averages during the dry and the rainy periods respectively of $18.2^{\circ} \mathrm{C}$ and $26^{\circ} \mathrm{C}$ in Tanque Grande and of $16{ }^{\circ} \mathrm{C}$ and $22.6{ }^{\circ} \mathrm{C}$ in Cabuçu (Table 1). Both reservoirs exhibited low conductivity and $\mathrm{pH}$, while Tanque Grande also presented low nutrient concentration. In Tanque Grande, total nitrogen concentrations ranged from $77.3 \mu \mathrm{g} \mathrm{L} \mathrm{L}^{-1}$ to $254.2 \mu \mathrm{g} \mathrm{L}^{-1}$ and total phosphorus from $8.3 \mu \mathrm{g} \mathrm{L}^{-1}$ to $18.0 \mu \mathrm{g} \mathrm{L}^{-1}$. Soluble reactive silicon concentrations were similar between the two climatic periods, with slightly higher values during the rainy period $\left(4.6 \mu \mathrm{g} \mathrm{L}^{-1}\right.$ to $\left.6.1 \mu \mathrm{g} \mathrm{L}^{-1}\right)$, while chlorophyll- $a$ was higher during the dry period (3.8 $\mu \mathrm{g} \mathrm{L}^{-1}$ to $\left.10.1 \mu \mathrm{g} \mathrm{L}^{-1}\right)$, as shown in Table 1 .

In the Cabuçu reservoir, total nitrogen ranged from $218.5 \mu \mathrm{g} \mathrm{L}^{-1}$ to $861.8 \mu \mathrm{g} \mathrm{L}^{-1}$, with the greatest values during the rainy period, while total phosphorus values from $12.2 \mu \mathrm{g} \mathrm{L}^{-1}$ to $23.1 \mu \mathrm{g} \mathrm{L}^{-1}$. Soluble reactive silicon ranged 
Table 1. Water limnological variables of the reservoirs Tanque Grande (TG) and Cabuçu (CB) during the dry and rainy periods. Temp: Temperature; Cond: conductivity; TN: total nitrogen; TP: total phosphorous; SRS: soluble reactive silicon; Chlo-a: chlorophyll $a$.

\begin{tabular}{|c|c|c|c|c|c|c|c|c|c|}
\hline $\begin{array}{l}\text { Sampling } \\
\text { station }\end{array}$ & $\begin{array}{c}\text { Depth } \\
(\mathrm{m}) \\
\end{array}$ & $\begin{array}{c}\text { Temp } \\
\left({ }^{\circ} \mathrm{C}\right) \\
\end{array}$ & $\begin{array}{c}\text { Cond } \\
\mu S \mathrm{~cm}^{-1}\end{array}$ & $\mathrm{pH}$ & $\begin{array}{c}\text { Secchi } \\
(\mathrm{m})\end{array}$ & $\begin{array}{c}\mathrm{TN} \\
\mu \mathrm{g} \mathrm{L}^{-1}\end{array}$ & $\begin{array}{c}\text { TP } \\
\mu \mathrm{g} \mathrm{L}^{-1}\end{array}$ & $\begin{array}{c}\text { SRS } \\
\mathrm{mg} \mathrm{L}^{-1}\end{array}$ & $\begin{array}{c}\text { Chlo-a } \\
\mu g \text { L }^{-1}\end{array}$ \\
\hline \multicolumn{10}{|c|}{ DRY PERIOD } \\
\hline TG1 & 2.3 & 18.3 & 52.5 & 6.7 & 1.5 & 77.3 & 8.2 & 4.7 & 6.5 \\
\hline TG2 & 2.6 & 19.7 & 50 & 6.2 & 1.7 & 122.4 & 7.5 & 4.6 & 10.1 \\
\hline TG3 & 3.0 & 16.5 & 58.5 & 5.9 & 1.6 & 227.7 & 14.0 & 4.7 & 9.8 \\
\hline CB1 & 3.1 & 15.8 & 39.3 & 6.1 & 3.1 & 218.4 & 12.9 & 5.3 & 4.0 \\
\hline CB2 & 9.0 & 15.8 & 38.6 & 5.8 & 2.7 & 269.5 & 15.6 & 5.4 & 3.9 \\
\hline CB3 & 10.0 & 16.3 & 38.7 & 6.2 & 3.1 & 586.9 & 12.2 & 4.9 & 4.8 \\
\hline \multicolumn{10}{|c|}{ RAINY PERIOD } \\
\hline TG1 & 2.1 & 26.1 & 65 & 7 & 0.7 & 254.1 & 17.9 & 6.1 & 4.3 \\
\hline TG2 & 2.5 & 26.3 & 63 & 6.8 & 0.6 & 174.9 & 11.2 & 6.0 & 5.2 \\
\hline TG3 & 3.1 & 25.7 & 63.5 & 6.6 & 1.1 & 170.8 & 11.7 & 5.9 & 3.8 \\
\hline CB1 & 4.1 & 24.2 & 39.6 & 7.3 & 1.4 & 410.1 & 23.1 & 2.9 & 14.2 \\
\hline CB2 & 8.1 & 22.1 & 59 & 6.8 & 1.9 & 861.7 & 15.6 & 3.3 & 29.9 \\
\hline CB3 & 9.8 & 21.4 & 60.3 & 6.7 & 2.1 & 719.6 & 17.4 & 3.3 & 34.5 \\
\hline
\end{tabular}

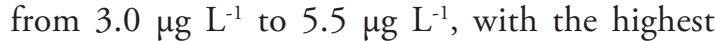
values during the dry period. Chlorophyll-a $\left(3.9 \mu \mathrm{g} \mathrm{L}-1\right.$ to $\left.34.5 \mu \mathrm{g} \mathrm{L}^{-1}\right)$ showed the greatest values during the rainy period (Table 1). Based on the annual average values of the Trophic State Index, both reservoirs were classified as oligotrophic, and their limnological features maintained as steady according to CETESB monitoring.

The diatom community was represented by 30 species classified into 20 genera (Table 2). The plankton showed the highest richness with three exclusive taxa: Navicula cryptocephala, Navicula neomundana and Ulnaria ulna. All taxa registered in the sediment were also present in the plankton while there were no species exclusive to this community. The surface sediments presented the lowest richness of the three compartments analyzed. In the case of the periphyton, six species, Encyonema neogracile, Eunotia pseudosudetica, Fragilaria tenera, Fragilaria capuccina, Frustulia saxonica and Ulnaria acus were exclusive of this compartment.

The highest diversity of plankton diatoms (annual average $=0.71-\mathrm{D})$ and the least species dominance (annual average $=0.2$ ) were found in the Tanque Grande reservoir during the two climatic periods. Moreover, the highest species richness (annual average $=23$ ) was found in this reservoir, mainly in the intermediate region and near the dam. In the Cabuçu reservoir, we observed the least species richness (annual average $=17$ ) and diversity (annual average $=0.51-D)$ and the greatest species dominance (0.4).
During the dry period, the community of planktonic diatoms at Tanque Grande reservoir was characterized by a high abundance of Staurosira construens, Aulacoseira tenella, Discostella stelligera, Brachysira brebissonii, Aulacoseira ambigua and Pseudostaurosira parasitica, being Staurosira construens the most abundant species. During the rainy period, Staurosira construens, Discostella stelligera, Achnanthidium tropicocatenatum, Staurosirella pinnata, Brachysira brebissonii and Aulacoseira tenella were the most abundant species at this reservoir. Staurosira construens was the species that contributed most to the total abundance in the reservoir together with Aulacoseira tenella, Discostella stelligera and Brachysira brebissonii, which therefore confirmed that the community structure of planktonic diatoms presented little variation in the reservoir if both climatic periods are considered.

At the Cabuçu reservoir, the community of planktonic diatoms did not show significant differences in the species composition between climatic periods. Discostella stelligera and Aulacoseira tenella presented high abundance at this reservoir during both climatic periods.

According to the dominance-diversity curve (Figure 2), a similar taxonomic structure was observed between sampling stations. Tanque Grande showed a greater number of rare species during the dry period, mainly at the station next to the tributary inflow (TG1), whereas the abundant species presented a more homogeneous distribution during the rainy period. Cabuçu had a less number of species than Tanque Grande and therefore, there was a decrease in diversity. However, no considerable 
Table 2. Distribution of the diatoms with their respective codes and species richness $(S)$ in the plankton, surface sediments and periphyton of Tanque Grande (TG) and Cabuçu (CB) reservoirs.

\begin{tabular}{|c|c|c|c|c|c|c|c|}
\hline \multirow[t]{2}{*}{ Taxa } & \multirow[t]{2}{*}{ Code } & \multicolumn{2}{|c|}{ Plankton } & \multicolumn{2}{|c|}{$\begin{array}{c}\text { Surface } \\
\text { sediments }\end{array}$} & \multicolumn{2}{|c|}{ Periphyton } \\
\hline & & TG & CB & TG & CB & TG & CB \\
\hline $\begin{array}{l}\text { Achnanthidium tropicocatenatum G.C.Marquardt, C.E.Wetzel \& } \\
\text { Ector }\end{array}$ & ADTR & $\cdot$ & $\cdot$ & & & $\cdot$ & $\cdot$ \\
\hline Aulacoseira ambigua (Grunow) Simonsen & AAMB & • & - & & & & \\
\hline A. tenella (Nygaard) Simonsen & AUTL & $\cdot$ & • & • & • & • & • \\
\hline Brachysira brebissonii Ross in Hartley & BBRE & • & - & & & & \\
\hline B. microcephala (Grunow) Compère & BMIC & & • & & & $\cdot$ & • \\
\hline B. neoexilis Lange-Bertalot & BNEO & • & - & • & - & • & - \\
\hline Discostella stelligera (Cleve \& Grunov) Houk \& Klee & DSTE & - & - & - & - & - & - \\
\hline Encyonema neogracile Krammer & ENNG & & & & & • & - \\
\hline E. neomesianum Krammer & ENMS & - & - & - & - & - & - \\
\hline E. silesiacum (Bleisch in Rabenhorst) D.G. Mann & ELSE & $\cdot$ & • & & & $\cdot$ & • \\
\hline E. subminuta Krammer \& Reichardt & ESUM & $\cdot$ & • & & & • & - \\
\hline Eunotia sp1. Ehrenberg & ECAM & • & & • & - & & \\
\hline Eunotia desmogonioides Metzeltin \& Lange-Bertalot & EDMG & • & & - & - & • & \\
\hline E. juettnerae Lange-Bertalot in Lange-Bertalot et al. & EJUE & • & & $\cdot$ & - & • & - \\
\hline E. pseudosudetica Metzeltin, Lange-Bertalot \& García-Rodríguez & EPSD & & & & & • & - \\
\hline Fragilaria capucina Desmazières & FCAP & & & & & • & \\
\hline F. tenera (W.Smith) Lange-Bertalot & FTEN & & & & & • & - \\
\hline Frustulia saxonica Rabenhorst & FSAX & & & & & • & • \\
\hline Gomphonema gracile Ehrenberg & GGRA & • & • & • & - & • & • \\
\hline Nitzschia amphibia Grunow & NAMP & - & - & - & - & & \\
\hline Navicula cryptocephala Kützing & NCRY & $\cdot$ & • & & & & \\
\hline N. neomundana (Lange-Bertalot \& Rumrich) Lange-Bertalot et al. & NNEO & $\cdot$ & • & & & & \\
\hline Pinnularia subanglica Krammer & PSAG & • & & • & • & & \\
\hline Planothidium sp1. Round \& Bukhtiyarova & PLTD & • & & $\cdot$ & • & & \\
\hline Pseudostaurosira parasitica (W. Smith) Morales & PPRS & • & • & • & - & & \\
\hline $\begin{array}{l}\text { Sellaphora ventraloconfusa (Lange-Bertalot) Metzeltin \& } \\
\text { Lange-Bertalot }\end{array}$ & SVTC & • & & $\cdot$ & • & & \\
\hline Staurosira construens Ehrenberg & SCON & • & • & • & - & - & - \\
\hline Staurosirella pinnata (Ehrenberg) Williams \& Round & SPIN & $\cdot$ & • & & & • & • \\
\hline Ulnaria acus (Kützing) Aboal & UACU & & & & & • & - \\
\hline U. ulna (Nitzsch) Compère & UULN & - & & & & & \\
\hline $\mathrm{s}$ & & 23 & 17 & 14 & 14 & 19 & 17 \\
\hline
\end{tabular}

differences in the diatom communities were registered between the climatic periods.

The values of Simpson diversity index and evenness were higher at Tanque Grande reservoir, although both reservoirs showed similar diversity and evenness between the dry and the rainy periods (Figure 3).

Canonic Correspondence Analysis in the plankton summarized $50.7 \%$ of the total data variation in the first two axes (Axis 1: 0.313; Axis 2: 0.242 ). A high Pearson correlation between species and environmental data for both axes $(r=0.978$ and $r=0.963)$ indicated that the distribution of species was strongly related to the environmental variables. Monte Carlo permutation test was positive for both axes $(p=0.004$ and $p=0.018)$. According to the canonic coefficients, the main explanatory variables that contributed to the ordination of samples were the electric conductivity (axis 1) and total phosphorus (axis 2), as shown in Figure 4.

On the positive side of axis 1, all sampling units from Tanque Grande were associated with a high conductivity $(r=0.7)$. Five species of planktonic diatoms characterized Tanque Grande reservoir $(r>0.6)$, especially Encyonema silesiacum $(r=0.8)$ and Staurosira construens $(r=0.8)$. On the negative side of this axis, the sampling units of Cabuçu were related to a low conductivity and high total nitrogen concentrations $(r=-0.6)$. Five species were associated with the Cabuçu reservoir, especially Aulacoseira tenella $(r=-0.8)$ and 

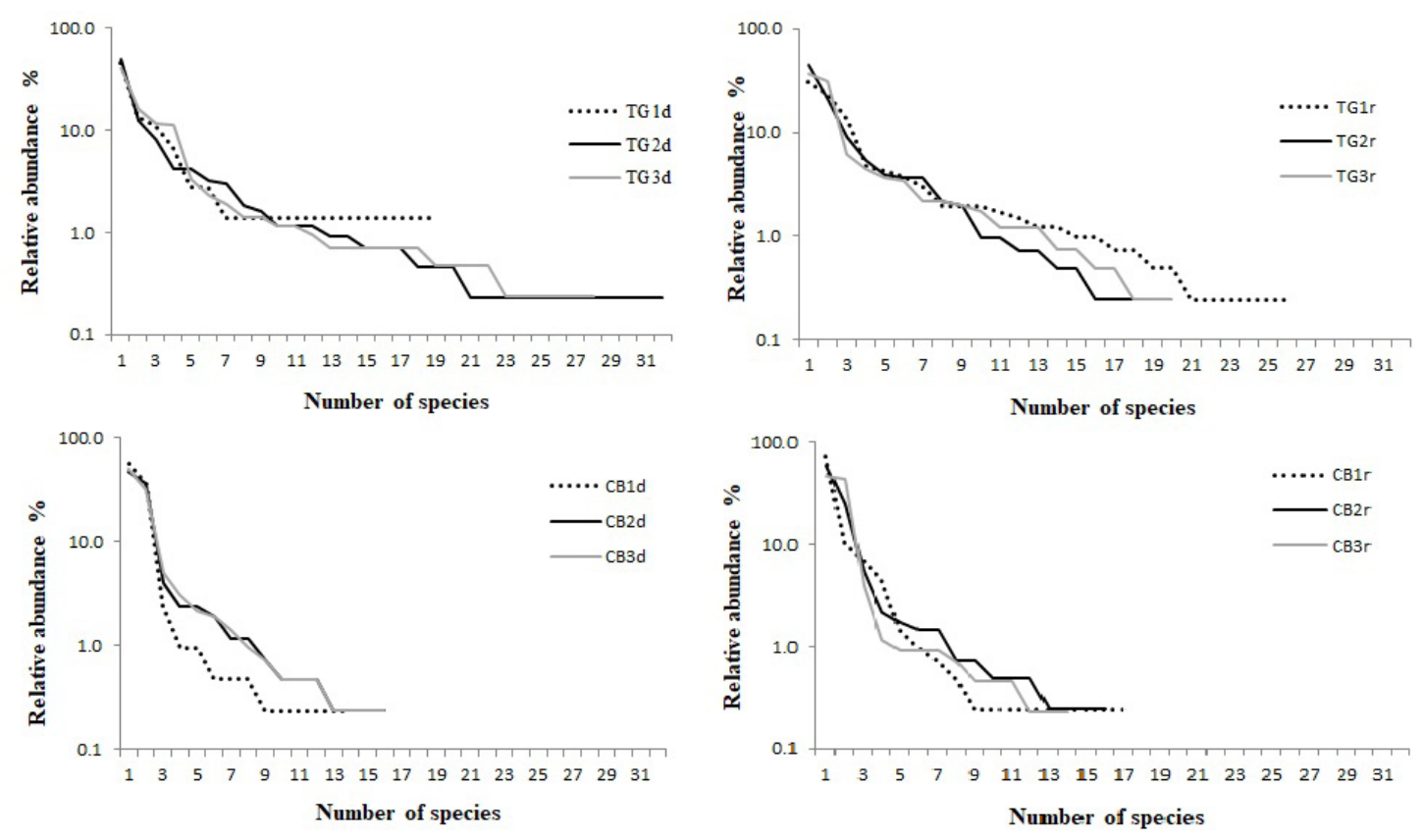

Figure 2. Dominance-diversity curve of the plankton diatoms at Tanque Grande (TG) and Cabuçu (CB) reservoirs during the dry (d) and rainy (r) periods. Axis y = base 10 logarithm.

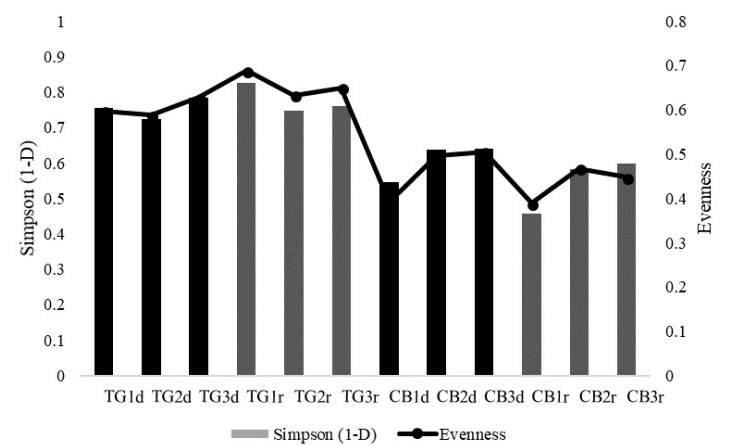

Figure 3. Simpson's diversity index and evenness of the planktonic diatoms of Tanque Grande (TG) and Cabuçu $(\mathrm{CB})$ reservoirs during the dry $(\mathrm{d})$ and rainy $(\mathrm{r})$ periods.

Discostella stelligera $(r=-0.7)$. Consequently, axis 1 showed the differences between reservoirs regarding the community structure of planktonic diatoms.

Axis 2 showed the influence of seasonal variations on the planktonic diatoms of Tanque Grande. On the negative side of this axis, sampling units of the rainy period were highly associated with a high total phosphorus $(r=-0.6)$ and characterized by Achnanthidium tropicocatenatum $(r=-0.6)$ and Brachysira neoexilis $(r=-0.6)$. The sampling units of the dry period were grouped on the positive side, associated with low total phosphorus, and characterized mainly by Brachysira brebissonii $(r=0.8)$. The CCA analysis evidenced that the distribution of species was influenced by differences in nutrient concentrations between the sampling stations, mainly of total nitrogen and conductivity.

The species composition of diatoms was similar between the surface sediments and the plankton, since most taxa were shared by both compartments. The dominance-diversity curve showed that the diatom community from the surface sediments was different between reservoirs, since Tanque Grande presented a larger number of rare species than Cabuçu (Figure 5). Simpson's diversity index revealed a low diversity and evenness and showed a low abundance of species, indicating a low differentiation of the community due to the abundance of a few species (Figure 6).

Staurosira construens, Aulacoseira tenella, Staurosirella pinnata and Discostella stelligera were the species that contributed most to the total abundance at Tanque Grande. The latter species was also highly abundant in the plankton. At Cabuçu, Staurosira construens, Aulacoseira tenella and Discostella stelligera showed the greatest abundance. The community composition of diatoms of the surface sediments was practically the same in both reservoirs. The greatest difference was found in the abundance percentage of species at each sampling station.

The Canonic Correspondence Analysis performed with 14 diatom species from surface sediment and five limnological variables (Figure 7) explained $67.2 \%$ of total data variation, resulting 


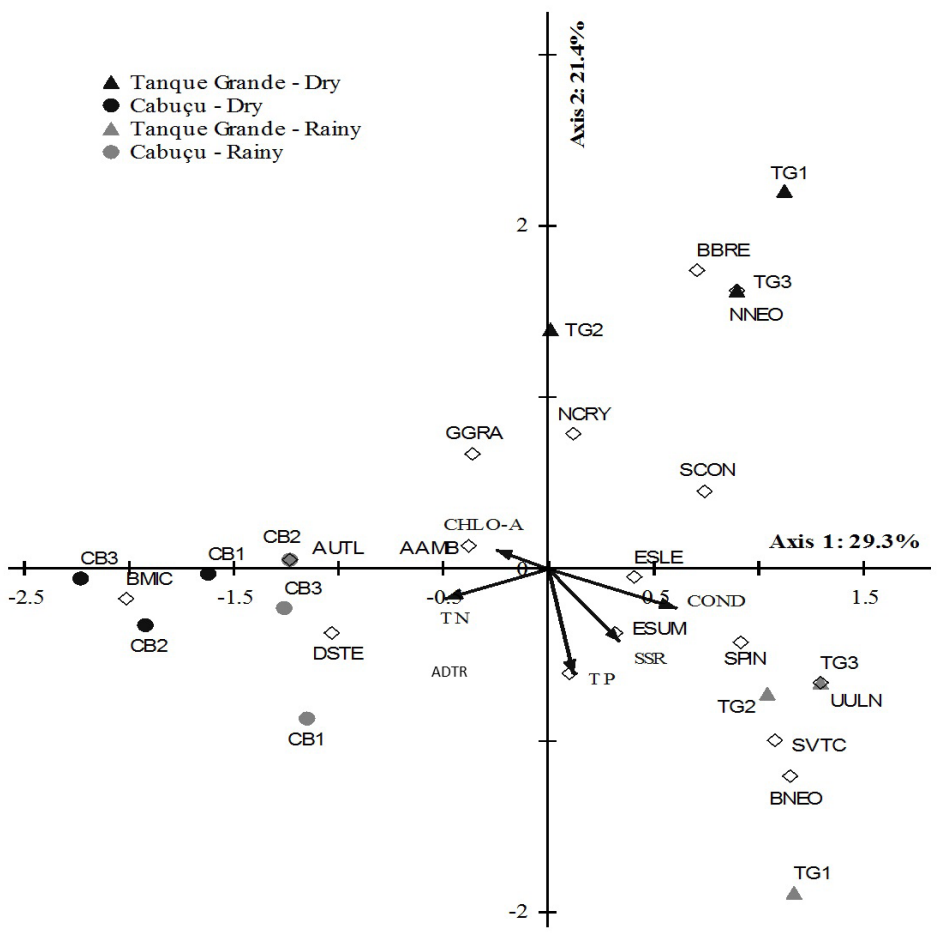

Figure 4. CCA ordination of the sampling units of Tanque Grande (TG) and Cabuçu (CB) reservoirs during the dry and rainy periods, based on four water abiotic variables (total nitrogen: TN; total phosphorus: TP; soluble reactive silicon: SSR; and electric conductivity: COND), Chlorophyll- $a$ and 16 planktonic species (species codes are shown in Table 2).
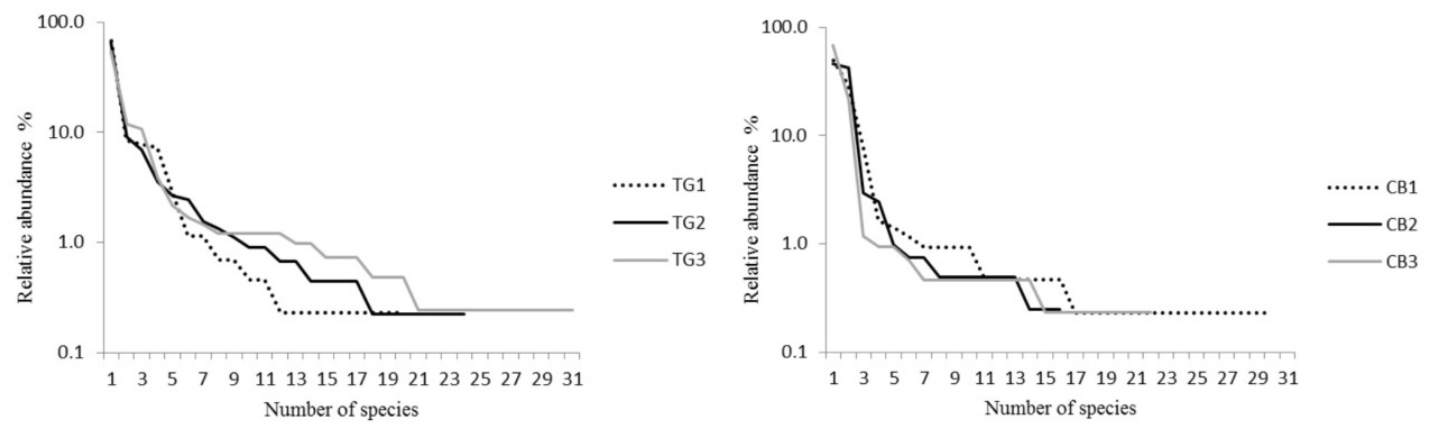

Figure 5. Dominance-diversity curve for the diatoms from surface sediments of Tanque Grande (TG) and Cabuçu (CB) reservoirs during the study period. Axis $y=$ base10 logarithm.

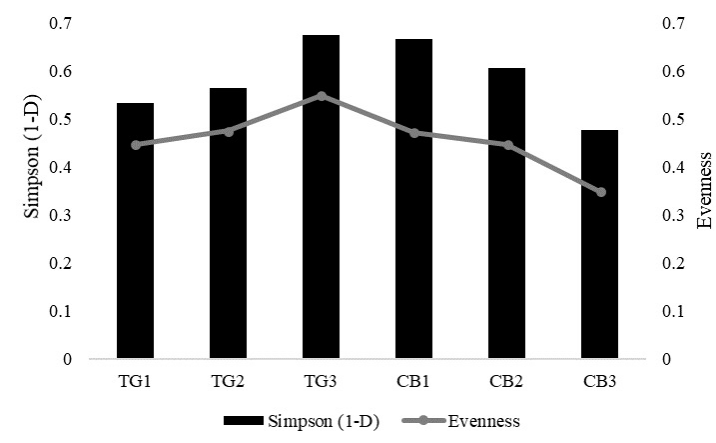

Figure 6. Simpson's diversity and evenness of the diatoms from surface sediments of Tanque Grande (TG) and Cabuçu (CB) reservoirs during the study period. in eigenvalues of 0.698 for axis 1 and of 0.309 for axis 2. The high Pearson correlation between species and environmental variables for the two first axes $(r=0.998$ and $r=0.997)$ indicated a strong relationship between the distribution of species and environmental variables. Monte Carlo permutation test was significant for both axes $(p=0.02)$. The main explanatory variables that contributed to the ordination of samples along axis 1 were total phosphorus and water transparency. On the positive side of axis 1, all sampling units of Tanque Grande were highly correlated with the least values of water transparency $(r=-0.9)$, total phosphorus $(r=-0.8)$, 


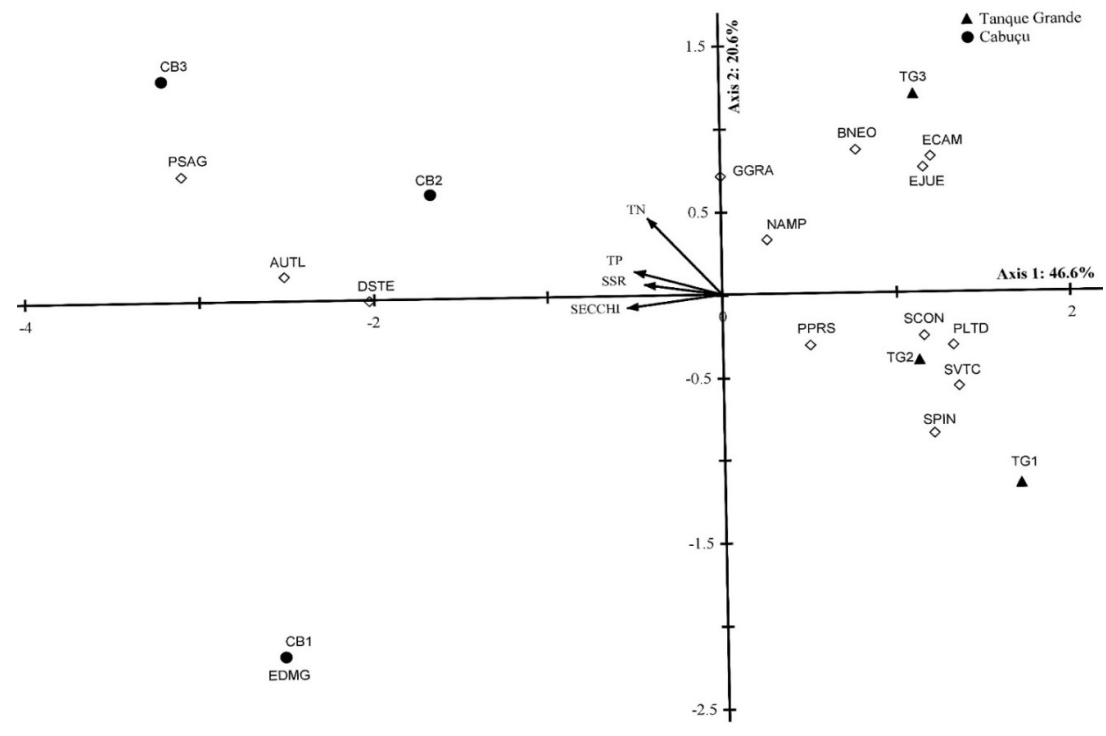

Figure 7. CCA ordination of the sampling stations of Tanque Grande (TG) and Cabuçu (CB) reservoirs based on four water abiotic variables (total nitrogen: TN; total phosphorus: TP; soluble reactive silicon: SSR; and water transparency: SECCHI) and 14 species from surface sediment (species codes are shown in Table 2).

soluble reactive silicon $(r=-0.7)$, and total nitrogen $(r=-0.7)$. Two species, Staurosira construens $(r=0.9)$ and Planothidium sp. $(r=0.9)$, characterized this reservoir. On the negative side of axis 1 , all sampling units of Cabuçu reservoir were highly correlated with the limnological variables mentioned above and characterized by Aulacoseira tenella $(r=0.9)$ and Discostella stelligera $(r=0.7)$. Axis 2 showed the differences between sampling stations. The sampling stations located near the dam were grouped on the positive side of axis 1 , while the sampling stations located near to the main tributary were grouped on the negative side.

Although the composition of periphytic diatoms differed between Tanque Grande and Cabuçu reservoirs, a comparison regarding the species richness could not be performed because aquatic macrophytes were found only in one sampling station in each climatic period at Cabuçu reservoir. However, a greater number of species was observed during the dry period in the two reservoirs. The descriptive species at Tanque Grande during the dry period were Achnanthidium tropicocatenatum, Encyonopis subminuta and Brachysira neoexilis, being the last species the most common of these three regarding the total abundance in all sampling stations. During the rainy period, Brachysira neoexilis, Encyonema silesiacum, Staurosira construens, and Eunotia pseudosudetica were the most abundant. At stations TG01 and TG02,
Brachysira neoexilis contributed most to the total abundance, whereas at TG03 Encyonema silesiacum was the most abundant. At Cabuçu reservoir, Achnanthidium tropicocatenatum was the most abundant species during the two studied periods, contributing significantly to the total abundance during the rainy period while Fragilaria tenera and Discostella stelligera had a significant contribution during the dry period.

Brachysira neoexilis showed an expressive abundance at Tanque Grande, while Achnanthidium tropicocatenatum was the most abundant species at the Cabuçu, together with Encyonema silesiacum, Encyonopis subminuta, Fragilaria tenera, Discostella stelligera, Staurosira construens and Eunotia pseudosudetica.

Regarding the Simpson's index (Figure 8), the greatest diversity and high evenness were observed at Tanque Grande reservoir during the rainy period, indicating that this reservoir exhibited a high uniformity in the distribution of species' densities. In the case of Cabuçu, a low density of species was found during the two sampling periods.

The CCA of periphyton species and environmental variables (Figure 9) explained 65.5\% of total data variation, resulting in eigenvalues of 0.289 for axis 1 and of 0.103 for axis 2 . A high Pearson correlation between species and limnological variables for the two first axes $(r=0.993$ and $r=0.103$, respectively) also indicated 
a strong correlation between the distribution of species and the limnological variables. Monte Carlo permutation test was significant for the two axes $(p=0.02)$. The main explanatory variables that contributed to the ordination of samples were chlorophyll- $a$ and soluble reactive silicon. The sampling units of Tanque Grande were grouped on the positive side of axis 1 and exhibited a high correlation with the least values of total phosphorus $(r=-0.5)$ and total nitrogen $(r=-0.6)$.

Brachysira neoexilis, Encyonema neogracile, Encyonopsis subminuta and Eunotia desmogonioides

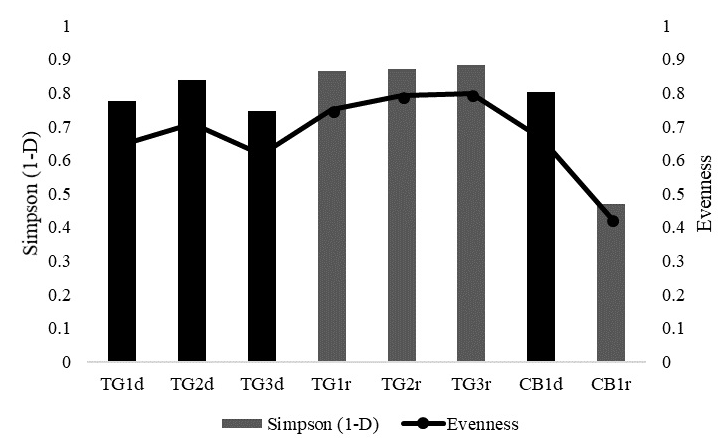

Figure 8. Simpson's diversity and evenness of Tanque Grande (TG) and Cabuçu (CB) reservoirs for the periphytic diatoms during the dry $(\mathrm{d})$ and rainy $(\mathrm{r})$ periods. characterized the reservoir Tanque Grande $(r>0.6)$. The sampling units of Cabuçu were grouped on the negative side of axis 1 , showing a high association with the concentrations of total phosphorus $(r=-0.5)$ and total nitrogen $(r=-0.6)$ and characterized by Brachysira microcephala, Fragilaria tenera and Aulacoseira tenella $(r \geq 0.7)$.

Along Axis 2, the reservoirs were differentiated by the climatic period. The sampling stations of Tanque Grande related to the dry period were grouped on the positive side of this axis, together with the only Cabuçu station of the rainy period, characterized by the concentrations of chlorophyll- $a(r=0.9)$ and the presence of Achnanthidium tropicocatenatum $(r>0.6)$. The negative side of axis 2 grouped all sampling units of the rainy period of Tanque Grande as well as the only sampling unit of the dry period of Cabuçu, associated with the concentrations of reactive soluble silicon $(r=-0.9)$ and the presence of Staurosira construens $(r>0.6)$. Thus, according to the CCA, the periphytic community of diatoms was influenced by the contrasting climatic periods and concentration of nutrients.

\section{Discussion}

The reservoirs of Tanque Grande and Cabuçu constitute the Guarulhos Producing System and provide autonomy to the municipality in relation

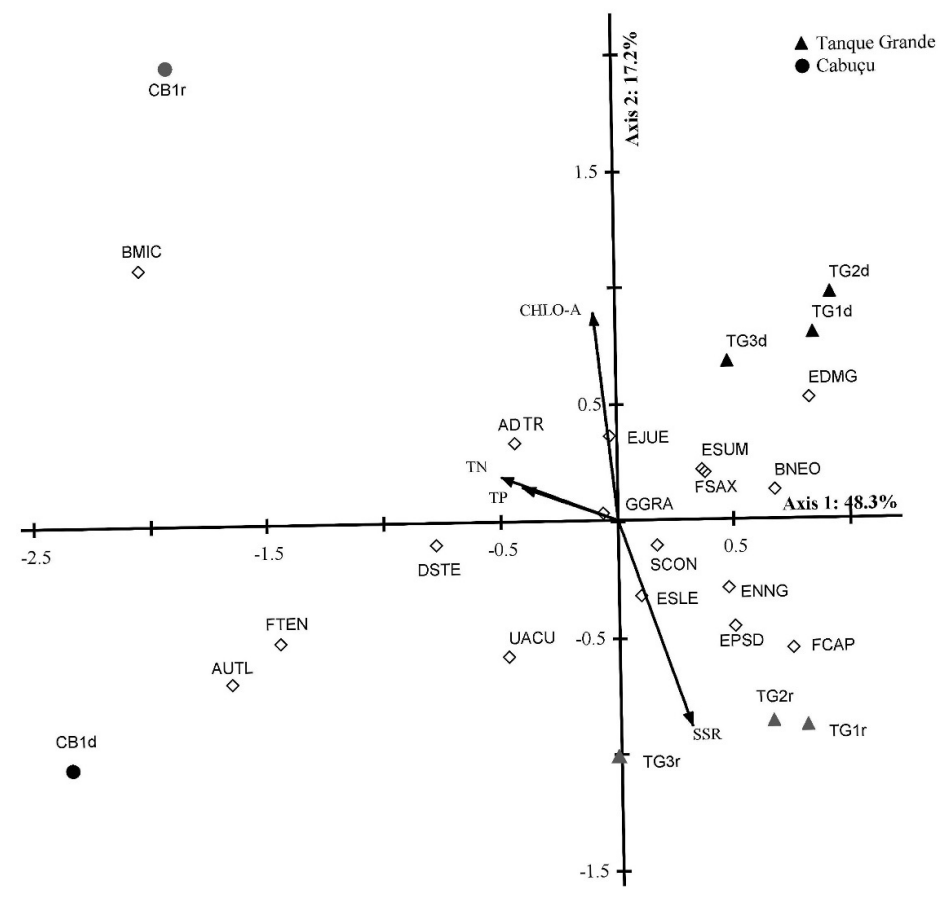

Figure 9. CCA ordination of the sampling units of Tanque Grande (TG) and Cabuçu (CB) reservoirs during the dry (d) and rainy (r) periods, based on three water abiotic variables (TN: total nitrogen; TP: total phosphorus; SSR: soluble reactive silicon), Chlorophyll-a (Chlo-a) and 17 periphyton species (species codes are shown in the Table 2). 
to the public water supply. The limnological characteristics showed that both reservoirs are still relatively preserved and have a low anthropogenic impact, because they are located in "Parque Estadual da Cantareira" (PEC), an important reserve that protects a fragment of the Atlantic Forest and its water resources.

Our study showed that the reservoirs and the different studied compartments shared species, and that the abiotic variables influenced the structure of the planktonic and periphytic communities of diatoms. The sharing of species between compartments might be associated with the fact that the reservoirs are shallow, hence favored the interaction between the diatoms from different compartments. We found a greater diatom biodiversity in the plankton, in contrast to Almeida \& Bicudo (2014) who found a greater biodiversity in the surface sediments. In agreement with Rosini et al. (2016), who reported changes in the structure of the phytoplankton in an oligotrophic reservoir, we found that the distribution of species in the reservoirs varied according to environmental factors.

Our results indicated that Tanque Grande and Cabuçu reservoirs can be classified as oligotrophic, corroborating the previous classification by CETESB (2013). Comparing the results obtained in the present study with previous studies (Arcifa et al., 1981), both reservoirs can still be considered within the expected standards for oligo-mesotrophic reservoirs. Although the two reservoirs have the same trophic status, our CCA analysis separated the two reservoirs. The climatic influence was evident mainly in Tanque Grande, in agreement with the results of Oliveira \& Bicudo (2017).

Algal communities are influenced by environmental factors, which might act together in selecting the ecological preferences of species. Furthermore, most diatom species are specific to a particular compartment and can be used to characterize these environments (Round et al., 1990). In studied reservoirs, the retention time, low nutrients concentration, $\mathrm{pH}$, and high light availability were responsible for the dominance and persistence of some diatom species.

Based on the results of the CCA, the total phosphorus concentration and conductivity were the main determinants of the structure community of planktonic diatoms at a seasonal scale. Staurosira construens was the most abundant species in the planktonic and periphytic compartments of Tanque Grande during both periods and tolerated different degrees of trophy (Moro \& Fürstenbeger, 1997). Two Aulacoseira species (A. tenella and A. ambigua) were also abundant and highly represented during the two climatic periods. These two species were found in high densities in oligotrophic to supereutrophic systems, related to turbulence events (Zalat, 2000; Cruces et al., 2001; 2006), variation in the reservoir depth, mixing regime (Caballero et al., 2006) and different degrees of eutrophication (Yang et al., 2008). During the rainy season, most species at Tanque Grande were benthic, although the upwelling to the plankton might have occurred due to water circulation (Spaulding \& Edlund, 2009).

In the Cabuçu reservoir, two species, Discostella stelligera and Aulacoseira tenella, were the most abundant in both climatic periods. The first species is typical of poor nutrient environments (Dam et al., 1994) and can be used for local biomonitoring. The second species was reported for oligotrophic and oligo-mesotrophic environments with slightly acid to neutral waters and high light availability (Bicudo et al., 2016; Zorzal-Almeida et al., 2017; Marquardt et al., 2018).

The diatom community of the surface sediments resembled the community of the plankton but showed differences in the densities between sampling stations. The total nitrogen and phosphorus concentrations as well as the underwater light availability contributed to the structuring of the diatom community at a spatial scale. In Tanque Grande, the greatest density of diatoms was found at the sampling stations located next to the inflow of the main tributaries. This result is in contrast with Thorton et al. (1990), who reported a less deposition of particles in regions near the tributary. Tanque Grande receives the influence of several small tributaries, which can explain the accumulation of diatoms in this region. At Cabuçu, there was a great influence of the water flux from tributaries, which hindered the sedimentation of fine particles (Thorton et al., 1990) and therefore, the diatoms showed the greatest densities in the pelagic region.

The descriptive taxa of the surface sediments and plankton were practically the same. Staurosira construens, Aulacoseira tenella, Staurosirella pinnata and Discostella stelligera contributed most to the total abundance of these compartments in both reservoirs. These species were recorded in recent sediment samples as well as in subfossil materials (Fontana \& Bicudo, 2009; 
Faustino et al., 2016). Considering that the two superficial centimeters of the sediments integrate one to two years of information and up to four years in protected systems with a low sedimentation rate (Smol, 2008), the present diatom community might be recognized as relatively constant during the entire study period. Consequently, the surface sediments behaved as an integrative (Reis et al., 2010) and cumulative reservoir of information associated with other compartments, mainly the plankton. This also demonstrated that the diatom community of sediments in the recent past is yet related to that existing in the water column, thus indicating that beyond the spatial integration there is also temporal integration.

Regarding the community structure of periphytic diatoms, chlorophyll- $a$ and soluble reactive silicon were the main variables that contributed to the differentiation between sampling stations according to the spatial scale. While Tanque Grande had higher values of chlorophyll- $a$ and lower values of soluble reactive silicon during the dry period, Cabuçu showed the inverse pattern. Brachysira neoexilis, which is distributed in oligo to mesotrophic environments (van Dam et al., 1994), showed an expressive contribution in Tanque Grande. In contrast, Encyonema silesiacum contributed greatly to the species abundance in the TG03 sampling station during the rainy season and was previously documented in the periphyton of lotic environments with high nutrients and conductivity (Pereira et al., 2013). On the other hand, an abundant species in Cabuçu reservoir, Achnanthidium tropicocatenatum, was recently described as characteristic of the periphyton and surface sediments in oligo-mesotrophic environments (Marquardt et al., 2017). This species can be mistaken with $A$. catenatum (Bily \& Marvan) Lange-Bertalot, deferring by the absence of sharply pointed apices and the colony formation. Other descriptive species of the community of periphytic diatoms in the studied reservoirs, such as Encyonema silesiacum, Encyonopis subminuta, Fragilaria tenera and Discostella stelligera were previously documented for oligo to mesotrophic environments (Dam et al., 1994; Hofmann, 1994; Moro \& Fürstenbeger, 1997). Seasonality affected the community structure of periphytic diatoms of the Guarulhos water supply system, including both species with a broad tolerance spectrum to environmental variations and those with specific nutrient requirements.
Our results evidenced that abiotic variables contributed significantly to the limnological variation in the reservoirs Tanque Grande and Cabuçu during the dry and rainy periods. Both reservoirs were classified as oligotrophic and their limnological features are being maintained by the CETESB's monitoring. The diatom communities of the plankton and surface sediments were taxonomically similar, demonstrating the integrative and cumulative role of the sediments. The descriptive species found in these two compartments might also be found in systems either with low or high nutrient concentrations, such as Cantareira, Alto Cotia, Guarapiranga, Cachoeira do França and Jurupara (Faustino et al., 2016; Zorzal-Almeida et al., 2017; Marquardt et al., 2017). We observed a trend toward the differentiation of plankton samples between dry and rainy periods, mainly at Tanque Grande. The abiotic variables also affected the community of periphytic diatoms, which had typically periphytic descriptive species found in oligo to eutrophic systems. In general, the diatom species composition changed between compartments (plankton, surface sediments and periphyton), and their abundances differed between the two climatic periods. Finally, the present study contributes to the knowledge of the biodiversity and autoecology of diatoms from the different compartments of oligotrophic reservoirs and its relationship with environmental variables.

\section{Acknowledgements}

This research was supported by "Fundação de Amparo à Pesquisa do Estado de São Paulo" (FAPESP, Project 2009/53898-9). SAO and CEMB thank "Conselho Nacional de Desenvolvimento Científico e Tecnológico" (CNPq) for a Master of Science Fellowship given to the first author and a research grant to the last one. The authors also thank William de Queiróz (Universidade de Guarulhos, Geoprocessing Laboratory) for the illustration of the study area, as well as the students of the Ecology Research Center of "Instituto de Botânica", São Paulo, SP.

\section{References}

ALMEIDA, P.D. and BICUDO, D.C. Diatomáceas planctônicas e de sedimentos superficiais em represas de abastecimento da Região Metropolitana de São Paulo, SP, Sudeste do Brasil. Hoehnea, 2014, 41(2), 187-207. http://dx.doi.org/10.1590/S223689062014000200004 . 
ARCIFA, M.S., CARVALHO, M.A.J., GIANESELLAGALVÃO, S.M.F. and SHIMIZU, G.Y. FROEHLICH, C.G. and CASTRO, R.M.C. Limnology of ten reservoirs in Southestern Brazil. Verhndlungen der Internationale Vereinignung der Limnologie, 1981, 21, 1048-1053.

BARBOSA, V.S. Ecologia de diatomáceas do reservatório Cabuçu, Guarulhos, SP. Qualidade da água, sazonalidade e correlação com parâmetros físicos e químicos. Geociências, 2012, 11, 5-18.

BARTOZEK, E.C.R., ZORZAL-ALMEIDA, S. and BICUDO, D.C. Surface sediment and phytoplankton diatoms across a trophic gradient in tropical reservoirs: new records for Brazil and São Paulo State. Hoehnea, 2018, 45(1), 69-92. http:// dx.doi.org/10.1590/2236-8906-51/2017.

BATTARBEE, R.W. Diatoms analysis. In: B.E. BERGLUND, ed. Handbook of Holocene Palaeohydrology. New York: John Wiley \& Sons, 1986, pp. 527-570.

BENNION, H. Surface-sediment diatom assemblages in shallow, artificial, enriched ponds and implications for reconstructing trophic status. Diatom Research, 1995, 10(1), 1-19. http://dx.doi.org/10.1080/0269 249X.1995.9705326.

BENNION, H., BATTARBEE, R.W., SAYER, C.D., SIMPSON, G.L. and DAVIDSON, T.A. Defining reference conditions and restoration targets for lake ecosystems using Paleolimnology: a synthesis. Journal of Paleolimnology, 2011, 45(4), 533-544. http:// dx.doi.org/10.1007/s10933-010-9419-3.

BERE, T. and TUNDISI, J.G. Epipsammic diatoms in streams influenced by urban pollution, São CarlosSP, Brazil. Brazilian Journal of Biology $=$ Revista Brasileira de Biologia, 2010, 70(4), 920-930. http:// dx.doi.org/10.1590/S1519-69842010000500002. PMid:21180895.

BICUDO, C.E.M. and MENEZES, M. Gêneros de algas de águas continentais do Brasil: chave para identificação e descriçóes. 2. ed. São Carlos: RiMa Editora, 2006.

BICUDO, C.E.M., MORANDI, L.L., ARAUJO, A., CARNEIRO, L.A. and BICUDO, D.C. Algas. In: M.I.M.S. LOPES, M. KIRIZAWA and M.M.R.F. MELO, eds. Patrimônio da Reserva Biológica do Alto da Serra de Paranapiacaba: a antiga Estação Biológica do Alto da Serra. São Paulo: Instituto de Botânica, 2009, pp. 187-212.

BICUDO, D.C., BICUDO, C.E.M., CASTRO, A.A.J. and PICELLI-VICENTIM, M.M. Diatomáceas (Bacillariophyceae) do trecho a represar do Rio Paranapanema (Usina Hidrelétrica de Rosana), Estado de São Paulo, Brasil. Hoehnea, 1993, 20, 47-68.

BICUDO, D.C., TREMARIN, P.I., ALMEIDA, P.D., ZORZAL-ALMEIDA, S., WENGRAT, S., FAUSTINO, S.B., COSTA, L.F., BARTOZEK,
E.C.R., ROCHA, A.C.R., BICUDO, C.E.M. and MORALES, E.A. Ecology and distribution of Aulacoseira species (Bacillariophyta) in tropical reservoirs from Brazil. Diatom Research, 2016, 31(3), 199-215. http://dx.doi.org/10.1080/026924 9X.2016.1227376.

BIRKS, H.H. and BIRKS, H.J.B. Multi-proxy studies in palaeolimnology. Archaeobotany, 2006, 15(4), 235251. http://dx.doi.org/10.1007/s00334-006-0066-6.

CABALLERO, M., VÁZQUEZ, G., LOZANOGARCÍA, S., RODRÍGUEZ, A., SOSA-NÁJERA, S., RUIZ-FERNÁNDEZ, A.C. and ORTEGA, B. Present limnological conditions and recent (ca. 340 yr) paleolimnogical of a tropical lake in the Sierra de Los Tuxtlas, eastern Mexico. Journal of Paleolimnology, 2006, 35(1), 83-97. http://dx.doi.org/10.1007/ s10933-005-7427-5.

COMPANHIA DE TECNOLOGIA DE SANEAMENTO AMBIENTAL - CETESB. Relatório técnico 2014: relatório de qualidade das águas interiores do Estado de São Paulo. São Paulo: CETESB, 2013, 434 p.

COMPANHIA DE TECNOLOGIA DE SANEAMENTO AMBIENTAL - CETESB. Relatório técnico 2014: qualidade de águas superficiais no Estado de São Paulo. Sáo Paulo: CETESB, 2015, $520 \mathrm{p}$.

COSTA-BÖDDEKER, S., BENNION, H., JESUS, T.A., ALBUQUERQUE, A.L.S., FIGUEIRA, R.C.L. and BICUDO, D.C. Paleolimnologically inferred eutrophication of a shallow, tropical, urban reservoir in southeast Brazil. Journal of Paleolimnology, 2012., 48(4), 751-766. http://dx.doi.org/10.1007/ s10933-012-9642-1.

CRUCES, F., URRUTIA, R., ARANEDA, A., TORRES, L., CISTERNAS, M. and VYVERMAN, W. Evolución trófica de Laguna Grande de San Pedro (VIII región, Chile) durante el último siglo, mediante el análisis de registros sedimentários. Revista Chilena de Historia Natural, 2001, 74(2), 407-418. http:// dx.doi.org/10.4067/S0716-078X2001000200015.

CRUCES, F., URRUTIA, R., PARRA, O., ARANEDA, A., TREUTLER, H., BERTRAND, S., FAGEL, N., TORRES, L., BARRA, R. and CHIRINOS, L. Changes in diatom assemblages in an Andean lake in response to a recent volcanic event. Archiv für Hydrobiologie, 2006, 165(1), 23-35. http://dx.doi. org/10.1127/0003-9136/2006/0165-0023.

DAM, H., MERTENS, A. and SINKELDAM, J. A coded checklist and ecological indicator values of freshwater diatoms from the Netherlands. Netherlands Journal of Aquatic Ecology, 1994, 28(1), 117-133. http://dx.doi.org/10.1007/BF02334251.

DENNYS, L. A check-list of the diatoms in the Holocene deposits of the western Belgian coastal plain with a survey of their apparent ecological requirements, 1: introduction, ecological code and complete list. 
Service Geologique de Belgique. Professional Paper, 1991, 246, 1-41.

FARIA, D.M., TREMARIN, P.I. and LUDWIG, T.A.V. Diatomáceas perifíticas da represa Itaqui, São José dos Pinhais, Paraná: Fragilariales, Eunotiales, Achnanthales e Gomphonema Ehrenberg. Biota Neotropica, 2010, 10(3), 415-427. http://dx.doi. org/10.1590/S1676-06032010000300035.

FAUSTINO, S.B., FONTANA, L., BARTOZEK, E.C.R., BICUDO, C.E.M. and BICUDO, D.C. Composition and distribution of diatom assemblages from core and surface sediments of a water supply reservoir in Southeastern Brazil. Biota Neotropica, 2016, 16(2), e20150129. http://dx.doi. org/10.1590/1676-0611-BN-2015-0129.

FONTANA, L. and BICUDO, D.C. Diatomáceas (Bacillariophyceae) de sedimentos superficiais dos reservatórios em cascata do Rio Paranapanema (SP/ PR, Brasil): Coscinodiscophyceae e Fragilariophyceae. Hoehnea, 2009, 36(3), 375-386. http://dx.doi. org/10.1590/S2236-89062009000300001.

FONTANA, L. and BICUDO, D.C. Biodiversidade e distribuição das diatomáceas (Bacillariophyceae) de sedimentos superficiais nos reservatórios em cascata do rio Paranapanema (SP/PR, Brasil). Hoehnea, 2012, 39(4), 587-612. http://dx.doi.org/10.1590/ S2236-89062012000400007.

FONTANA, L., ALBUQUERQUE, A.L.S., BRENNER, M., BONOTTO, D.M., SABARIS, T.P.P., PIRES, M.A.F., COTRIM, M.E.B. and BICUDO, D.C. The eutrophication history of a tropical water supply reservoir in Brazil. Journal of Paleolimnology, 2014, 51(1), 29-43. http://dx.doi.org/10.1007/s10933013-9753-3.

GOLTERMAN, H.L., CLYMO, R.S. and OHMSTAD, M.A. Methods for physical and chemical analysis of freshwaters. 2nd ed. Oxford: Blackwell, 1978.

HOFMANN, G. Aufwuchs diatoms in Seen und ihre Eignung als Indikatoren der Trophie. Bibliotheca Diatomologica, 1994, 30, 1-241.

LACAVA, M.A., OLIVEIRA, A.M.S. and PEREIRAFILHO, J.P. Comportamento hídrico de superfície da bacia do Rio Cabuçu de Cima, Parque Estadual da Cantareira, Guarulhos, SP. Revista Brasileira de Geomorfologia, 2009, 10(1), 23-30. http://dx.doi. org/10.20502/rbg.v10i1.114.

LOBO, E.A. and CALLEGARO, V.L.M and BENDER, E.P. Utilização das algas diatomáceas epilíticas como indicadoras da qualidade da água em rios e arroios da Regiāo Hidrográfica de Guaiba, RS, Brasil. Santa Cruz do Sul: Edunisc, 2002.

MARQUARDT, G.C., COSTA, L.F., BICUDO, D.C., BICUDO, C.E.M., BLANCO, S., WETZEL, C.E. and ECTOR, L. Type analysis of Achnanthidium minutissimum and $A$. catenatum and description of A. tropicocatenatum sp. nov. (Bacillariophyta), a common species in Brazilian reservoirs. Plant Ecology and Evolution, 2017, 150(3), 313-330. http://dx.doi. org/10.5091/plecevo.2017.1325.

MARQUARDT, G.C., PADIAL, A.A. and BICUDO, C.E.M. Variance partitioning of deconstructed tropical diatom communities in reservoirs cascade. Aquatic Sciences, 2018, 80(2), 17. http://dx.doi. org/10.1007/s00027-018-0571-6.

MARQUARDT, G.C., ROCHA, A.C.R., WETZEL, C.E., ECTOR, L. and BICUDO, C.E.M. Encyonema aquasedis sp. nov. and Kurtkrammeria salesopolensis sp. nov.: two new freshwater diatom species (Cymbellales, Bacillariophyceae) from an oligotrophic reservoir in southeastern Brazil. Phytotaxa, 2016, 247(1), 62-74. http://dx.doi. org/10.11646/phytotaxa.247.1.4.

MCCUNE, B. and MEFFORD, M.J. PC-ORD Multivariate analysis of ecological data. Version 6.0. Gleneden Beach, Oregon: MjM Software, 2011.

MORESCO, C., TREMARIN, P.I., LUDWIG, T.A.V. and RODRIGUES, L. Diatomáceas perifíticas abundantes em três córregos com diferentes açóes antrópicas em Maringá, PR, Brasil. Revista Brasileira de Botanica. Brazilian Journal of Botany, 2011, 34(3), 359-373. http://dx.doi.org/10.1590/S010084042011000300010 .

MORO, R.S. and FÜRSTENBEGER, C.B. Catálogo dos principais parâmetros ecológicos de diatomáceas não-marinhas. Ponta Grossa: Editora da Universidade Estadual de Ponta Grossa, 1997.

MOUTINHO, S.O., GARCIA, M.J. and OLIVEIRA, P.E. Flora de diatomáceas do Reservatório Cabuçu, Município de Guarulhos (SP): análise qualitativa. Geociências, 2007, 6, 32-62.

MOZETO, A.A. Sedimentos e particulados lacustres: amostragem e análises biogeoquímicas. In: C.E.M. BICUDO, and D.C. BICUDO, orgs. Amostragem em Limnologia. São Carlos: RiMa Editora, 2004, pp. 295-341.

OLIVEIRA, S.A. and BICUDO, C.E.M. Seasonal variation of limnological features and trophic state index of two oligotrophic reservoirs of southeast Brazil. Brazilian Journal of Biology $=$ Revista Brasileira de Biologia, 2017, 77(2), 323-331. http://dx.doi. org/10.1590/1519-6984.14015. PMid:27683805.

PAPPAS, J.L. and STOERMER, E.F. Quantitative method for determining a representative algal sample count. Journal of Phycology, 1996, 32(4), 693-696. http://dx.doi.org/10.1111/j.00223646.1996.00693.x.

PEREIRA, T.A., FELISBERTO, S.A. and FERNANDES, V.O. Longitudinal variation of periphytic algal community structure in a tropical river. Brazilian Journal of Botany, 2013, 36(4), $267-$ 277. http://dx.doi.org/10.1007/s40415-013-0034-1. 
PIASENTIN, A.M., SEMENSATTO-JUNIOR, D.L., SAAD, A.R., MONTEIRO-JUNIOR, A.J. and RACZKA, M.F. Índice de Qualidade da Água (IQA) do reservatório Tanque Grande Guarulhos (SP): Análise sazonal e efeitos do uso e ocupação do solo. Geociências, 2009, 28, 305-317.

POMPÊO, M.L.M. and MOSCHINI-CARLOS, V. Macrófitas aquáticas e perifiton: aspectos ecológicos e metodológicos. São Carlos: RiMa Editora, 2003.

REIS, A., PARKER, A. and ALENCOÃO, A. Avaliação da qualidade de sedimentos em rios de montanha: um caso de estudo no norte de Portugal. Revista Recursos Hidricos, 2010, 31, 87-97.

ROSINI, E.F., TUCCI, A., CARMO, C.F., ROJAS, N.E.T., BARROS, H.P. and MALLASEN, M. Changes in phytoplankton spatial and temporal dynamics in a Brazilian tropical oligotrophic reservoir after net cage installation. Brazilian Journal of Botany, 2016, 39(2), 569-581. http://dx.doi.org/10.1007/ s40415-016-0259-x.

ROUND, F.E., CRAWFORD, R.M. and MANN, D.G. The diatoms: biology \& morphology of the genera. New York: Cambridge University Press, 1990.

SALOMONI, S.E., ROCHA, O., CALLEGARO, V.L. and LOBO, E.A. Epilithic diatoms as indicators of water quality in the Gravataí river, Rio Grande do Sul, Brazil. Hydrobiologia, 2006, 559(1), 233-246. http:// dx.doi.org/10.1007/s10750-005-9012-3.

SARTORY, D.P. and GROBBELAAR, J.E. Extraction of chlorophyll a from freshwater phytoplankton for spectrophotometric analysis. Hydrobiologia, 1984, 114(3), 177-187. http://dx.doi.org/10.1007/ BF00031869.

SCHNECK, F., TORGAN, L.C. and SCHWARZBOLD, A. Diatomáceas epilíticas em riacho de altitude no Sul do Brasil. Rodriguésia, 2008, 59(2), 325-338. http:// dx.doi.org/10.1590/2175-7860200859205.

SILVA, C., OLIVEIRA, A.M.S., FIGUEIRA, R.C.L., SEMENSATTO, D. and LABUTO, G. Estudo do assoreamento do Reservatório Tanque Grande, Guarulhos (SP). Geociências, 2011, 30, 253-267.

SMOL, J.P. Pollution of lakes and rivers: a paleoenvironmental perspective. 2nd ed. Oxford: Wiley-Blackwell Publishing, 2008.

SMOL, J.P. and STOERMER, E.F. The diatoms: applications for the environmental and Earth Sciences. New York: Cambridge University Press, 2010. http:// dx.doi.org/10.1017/CBO9780511763175.

SPAULDING, S. and EDLUND, M. Brachysira. In: U.S. DEPARTMENT OF THE INTERIOR, U.S. GEOLOGICAL SURVEY. Diatoms of the United States. Colorado: Diatoms of North America, 2009 [viewed 30 September 2017]. Available from http:// westerndiatoms.colorado.edu/taxa/genus/Brachysira

THORTON, K.W., KIMMEL, B.L. and PAYNE, F.E. Perspectives on reservoir limnology. In: K.W. THORTON, B.L. KIMMEL and F.E. PAYNE, eds. Reservoir limnology: ecological perspectives. New York: Wiley-Interscience, 1990.

TREMARIN, P.I., BERTOLLI, L.M., FARIA, D.M., COSTIN, J.C. and LUDWIG, T.A.V. Gomphonema Ehrenberg and Gomphosphenia Lange-Bertalot (Bacillariophyceae) from Maurício river, Paraná, Brazil. Biota Neotropica, 2009, 9(4), 111-130. http:// dx.doi.org/10.1590/S1676-06032009000400013.

TREMARIN, P.I., MOREIRA-FILHO, H. and LUDWIG, T.A.V. Pinnulariaceae (Bacillariophyceae) do rio Guaraguaçu, bacia hidrográfica litorânea paranaense, Brasil. Acta Botanica Brasílica, 2010, 24(2), 335-353. http://dx.doi.org/10.1590/S010233062010000200005 .

VALDERRAMA, J.C. The simultaneous analysis of total nitrogen and total phosphorus in natural waters. Marine Chemistry, 1981, 10(2), 109-122. http:// dx.doi.org/10.1016/0304-4203(81)90027-X.

WEHR, J.D. and SHEATH, R.G. Freshwater Algae of North America: ecology and classification. San Diego: Academic Press, 2003.

WENGRAT, S., MARQUARDT, G.C., BICUDO, D.C., BICUDO, C.E.M., WETZEL, C.E. and ECTOR, L. Type analysis of Cymbella schubartii and two new Encyonopsis species (Bacillariophyceae) from southeastern Brazil. Phytotaxa, 2015, 221(3), 247264. http://dx.doi.org/10.11646/phytotaxa.221.3.3.

YANG, X., ANDERSON, N.J., DONG, X. and SHEN, J.I. Surface sediment diatom assemblages and epilimnetic total phosphorus in large, shallow lakes of the Yangtze floodplain: their relationships and implications for assessing long-term eutrophication. Freshwater Biology, 2008, 53(7), 1273-1290. http:// dx.doi.org/10.1111/j.1365-2427.2007.01921.x.

ZALAT, A.A. Distribution and paleoecological significance of fossil diatom assemblages from the Holocene sediments of Lake Manzala Egypt. Diatom Research, 2000, 15(1), 167-190. http://dx.doi.org/1 0.1080/0269249X.2000.9705491.

ZORZAL-ALMEIDA, S., BINI, L.M. and BICUDO, D.C. Beta diversity of diatoms is driven by environmental heterogeneity, spatial extent and productivity. Hydrobiologia, 2017, 800(1), 7-16. http://dx.doi.org/10.1007/s10750-017-3117-3.

Received: 14 July 2017 Accepted: 03 August 2018 